\title{
NOVE KNJIŽNIČNE USLUGE \\ ZA DJECU I MLADE: STEM-RADIONICE \\ U GRADSKOJ KNJIŽNICI ZADAR
}

\author{
NEW LIBRARY SERVICES FOR CHILDREN \\ AND YOUTH: STEM WORKSHOPS IN THE ZADAR \\ PUBLIC LIBRARY
}

\begin{abstract}
Milko Belevski
Gradska knjižnica Zadar

milko@gkzd.hr
\end{abstract}

UDK / UDC 025.5-053.3-053.6(497.5 Zadar):004

Stručni rad / Professional paper

Primljeno / Received: 15. 2. 2018.

Prihvaćeno / Accepted: 27. 5. 2018.

\section{Sažetak}

Cilj. Rad ukazuje na značaj organiziranja i provođenja STEM-programa, značaj edukacije, poticanja na inovativan i kreativan rad, usmjeravanja, osvještavanja novih tehnologija i njihove primjene kod djece i mladih.

Pristup/metodologija. Rad opisuje provedbu STEM-radionica u Gradskoj knjižnici Zadar te metodom anketnog upitnika ispituje zadovoljstvo polaznika radionica, učenika 5., 6. i 7. razreda osnovnih škola.

Rezultat. Iz rezultata provedenog istraživanja uočeno je izrazito zadovoljstvo sudionika organizacijom i ponuđenim sadržajem edukativnih STEM-programa u Gradskoj knjižnici Zadar.

Praktična primjena. Knjižničari i učenici osnovnih i srednjih škola kao aktivni sudionici STEM-programa razmjenom iskustava, pripremom programa i edukacijom razvijaju svoje vještine, usvajaju nova znanja o korištenju 3D-printera, 3D-skenera i

Vjesnik bibliotekara Hrvatske 61, 1(2018), 363-393

ISSN 0507-1925

(C) VBH 2018. 
3D-olovke, kao i osnova 3D-modeliranja i područja robotike (sastavljanje robotskih setova, osnove robotike, grafičkog programiranja i elektronike).

Originalnost/vrijednost. Rad nastoji ukazati na potrebu i značaj kontinuiranog provođenja STEM-programa u knjižnicama za djecu i mlade. Donosi pregled drugih STEM-inicijativa u Hrvatskoj. U radu se pored opisanih primjera STEM-programa koji se provode u Gradskoj knjižnici Zadar navodi i niz tehničkih podataka i popis opreme koja je korisna knjižničarima zainteresiranim za organizaciju i provedbu STEM-programa.

Ključne riječi: Američki kutak Zadar, Croatian Makers liga, program GENERATOR, Mali znanstvenici, narodne knjižnice, nove tehnologije, STEM-program

\begin{abstract}
Purpose. The paper points out the importance of the organization and implementation of STEM programs, education, motivation for innovative and creative work, guidance, and raising awareness of children and youth about new technologies and its applications.
\end{abstract}

Approach/Methodology. The paper describes the implementation of STEM workshops in the Zadar Public Library and examines, by means of a survey questionnaire, the satisfaction of 5th, 6th and 7th grade elementary school students who participated in the workshops.

Results. Analysis of the conducted research shows the high level of participant's satisfaction with the organization and the content of the educational STEM programs of the Zadar Public Library.

Practical use. As participants of STEM programs, librarians and elementary and high school students develop their skills and acquire new knowledge about using 3D printers, 3D scanners and 3D pens together with the basics of 3D modelling and robotics (assembling of robotic sets, robotics basics, graphical programming and electronics).

Originality/Value. The paper strives to emphasize the need for continuous conducting of STEM programs for children and youth at libraries . It also brings an overview of other STEM initiatives in Croatia. Besides the described Zadar Public Library STEM programs, the paper also brings an array of technical information and equipment useful for librarians interested in the organization and implementation of STEM programs.

Keywords: American Corner Zadar, Croatian Makers League, Generator program, Little Scientists, new technologies, public libraries, STEM program 


\section{Uvod}

Narodne knjižnice važni su promotori čitanja, obrazovanja i opće kulture, odnosno najrazličitijih oblika pismenosti i informiranosti. U vremenu globalizacije one se mijenjaju i prilagođavaju modernizaciji društva. Knjižničari cjeloživotnim učenjem nastoje odgovoriti na potrebe današnjih korisnika kako bi knjižnice ispunile svoje zadaće i poslanje. ${ }^{1}$ Pojavom i ponudom novih medija i tehnologija te osmišljavanjem novih knjižničnih sadržaja i usluga, namijenjenih svim vrstama korisnika, osobita pažnja posvećuje se brizi za djecu i mlade, odnosno novim generacijama korisnika. Kvantiteta i kvaliteta starih, ali i novih usluga ovisi o financijskim, prostornim i ljudskim resursima. Uvjeti i mogućnosti knjižnica razlikuju se u manjim i većim sredinama. U današnje vrijeme knjižnice su suočene s nepredvidivim tehnološkim trendovima i izazovima koji se naglo mijenjaju. Uporaba računala $\mathrm{i}$ internet postali su standard $\mathrm{u}$ radu. $\mathrm{S}$ druge strane, pojava novih tehnologija zahtijeva dodatne vještine i znanja i za knjižničare i za korisnike. Prema autorici Ivanki Stričević, pojavom i razvojem novih usluga i programa na odjelima za mladež u narodnim knjižnicama od knjižničara se očekuje niz kompetencija: socijalne kompetencije, usavršavanje profesionalnih kvalifikacija, sposobnost posredovanja i prenošenja znanja, poznavanje korištenja novih medija, poznavanje novih tehnologija te razvoj specifičnih znanja i vještina. ${ }^{2}$

Podsjetimo se, od izdanja prvih Smjernica za knjižnične usluge za mladež̉ 1996. godine do danas u području knjižničarstva dogodile su se velike globalne promjene vezane uz internet i nove informacijsko-komunikacijske tehnologije. Dajana Brunac ${ }^{4}$ (dječji knjižničar u Gradskoj knjižnici Zadar) naglašava da se u Smjernicama za knjižnične usluge za mladež, osim sadržaja vezanih uz informacijsko-komunikacijske tehnologije, naglašava i važnost planiranja i vrednovanja knjižničnih usluga za mlade te odgojno-obrazovna i društvena uloga knjižnice.

Navodi da nove tehnologije utječu na stil života, način komunikacije i korištenje slobodnog vremena kod djece ${ }^{5}$ i mladih. S obzirom na to da ih oni brzo i jedno-

\footnotetext{
1 Gradska knjižnica Zadar. Poslanje. [citirano: 2017-25-11]. Dostupno na: http://www.gkzd.hr/ content/poslanje-gradske-knji\%C5\%BEnice-zadar.

2 Usp. Stričević, I. Dječja knjižnica ukorak s vremenom. // Dječja knjižnica za novo tisućljeće: zbornik radova / priredila Ranka Javor. Zagreb: Knjižnice grada Zagreba, 2001. Str. 9.

3 IFLA-ine smjernice za knjižnične usluge i mladež. Zagreb: Hrvatsko knjižničarsko društvo, 2009. Str. 11-27.

4 Usp. Brunac, D. Recenzija Smjernica za knjižnične usluge za mladež. // Vjesnik bibliotekara Hrvatske 53, 1 (2010), 141-142. Dostupno i na: https://www.Hrvatsko knjižničarsko društvorustvo.hr/vjesnik-bibliotekara-hrvatske/index.php/vbh/article/view/450/445 [citirano: 2017-15-11].

5 IFLA-ine smjernice za knjižnične usluge za djecu. Zagreb : Hrvatsko knjižničarsko društvo, 2004. Str. 10-12.
} 
stavno usvajaju, potrebno je razumjeti i prihvatiti njihove potrebe. U tom smjeru knjižnice trebaju osigurati građu i usluge zanimljive mladima s ciljem poticanja čitanja, cjeloživotnog učenja i pismenosti.

U današnje informacijsko doba, koje donosi nove izazove, kao ključne riječi prate nas ovi pojmovi: informacija, znanje, pismenost, učenje, cjeloživotno učenje i učenje na daljinu, novi mediji i nove tehnologije, globalna komunikacija i $\mathrm{dr}^{6}$

Današnje knjižnice ne nude samo mogućnost čitanja, učenja i pružanja informacija nego su i mjesta zabave, druženja i kreativnog korištenja slobodnog vremena, u kojima se razvijaju sve slobodniji oblici rada s djecom (interaktivne, participativne, suradničke metode i radionički tip rada) koji su usmjereni na njihove interese i sklonosti te aktivnosti i izražavanje. ${ }^{7}$

Prema istraživanju Odjela za knjižničarstvo i informacijske znanosti Sveučilišta u Zadru o mogućnostima i konceptima knjižničnih usluga za mlade u narodnim knjižnicama u Hrvatskoj, moguća su tri osnovna modela knjižničnih usluga za mlade: knjižnica za mlade, odjel za mlade i programi za mlade. ${ }^{8}$ Navodi se da ne postoji jedinstven model knjižničnih usluga za mlade u svijetu, ali je moguće $\mathrm{u}$ organizacijskom i sadržajnom smislu identificirati osnovne koncepte usluga za mlade, a njihova organizacija utječe na građu, strategiju rada, usluge i posebne programe za mlade.

Gradska knjižnica Zadar u Strategiji razvoja od 2017. do 2020. godine ${ }^{9}$ naglašava viziju Knjižnice kao istinskog središta zajednice. SWOT-analizom postojećeg stanja kao snaga navode se međuinstitucionalna suradnja i suradnja s pojedincima, promicanje volontiranja, kontinuirano organiziranje različitih događanja te otvorenost prema novim uslugama i tehnologijama. Kao neke od slabosti navode se nedostatak prostora i nemogućnost formiranja odjela za mlade, nedostatak manjih prostora za grupni rad i edukaciju korisnika. Među prilikama navodi se kako velik interes korisnika za STEM-programima pruža mogućnost Knjižnici da se praćenjem razvoja tehnologija i ponudom novih programa i usluga nametne kao središnje mjesto stjecanja novih znanja. Buduće proširenje Gradske knjižnice Zadar na susjednu zgradu, u kojoj je planiran i smještaj zadar-

\footnotetext{
6 Usp. Štefančić, S. Uvodna riječ. // Knjižnica i mediji : zbornik radova / priredili Ranka Javor i Silko Štefančić. Zagreb: Knjižnice grada Zagreba, 2006. Str. 5.

7 Stričević, I. Nav. dj., str. 8.

8 Usp. Jelušić, S.; I. Stričević. Knjižnične usluge za mlade: modeli i koncepti. // Vjesnik bibliotekara Hrvatske 53, 1 (2010), 21-32. Dostupno i na: https://www.Hrvatsko knjižničarsko društvorustvo.hr/vjesnik-bibliotekara-hrvatske/index.php/vbh/article/view/443 [citirano: 2017-9-11].

9 Usp. Gradska knjižnica Zadar. Strategija razvoja od 2017. do 2020. godine. [citirano: 201725-11]. Dostupno na: http://www.gkzd.hr/sites/default/files/sluzbene_informacije/Strategija Gradske_knjiznice_Zadar_od_2017_do_2020.pdf.
} 
skog Centra za mlade, prilika je za uređenje dijela novog prostora i osmišljavanje usluga po uzoru na neki od makerspace ${ }^{10}$ knjižničnih modela. Osmišljavanje i uvođenje takvih specifičnih programa i uređenje namjenskog prostora znatno doprinosi popularizaciji knjižnica uopće, potiče interes korisnika te razvija i jača međuinstitucionalnu suradnju.

\section{STEM-programi u Gradskoj knjižnici Zadar}

Knjižnice nabavljaju, stručno obrađuju i nude usluge posudbe i korištenja knjižnične građe na raznim vrstama medija: knjige, muzikalije, časopisi, CD, CDROM, DVD, Blu-ray Disc, 3D Blu-ray Disc, digitaliziranu građu i drugo. Pod utjecajem novih tehnologija i novih medija razvijaju se i uvode nove knjižnične usluge i zbirke, pripremaju se i organiziraju razne aktivnosti za edukaciju korisnika o njihovu korištenju. Tako naprimjer djelatnici Mediateke ${ }^{11}$ i Američkog kutka Gradske knjižnice u Zadru ${ }^{12}$ u suradnji s Dječjim odjelom i ograncima Knjižnice (Arbanasi, Bili brig, Crno i Ploča) već nekoliko godina organiziraju edukativne radionice namijenjene djeci i mladima ${ }^{13}$ koje možemo okarakterizirati kao preteče današnjih STEM-programa ${ }^{14}$ : Kako koristiti iPad?, iPad foto, iPad ScratchJr, čitanje e-knjiga te niz drugih kreativnih $i P a d$-radionica.

iPad-uređaj (www.apple.com) prijenosno je računalo razvijeno kao platforma za audio-vizualne medije (film, glazba, e-knjige, internet, računalne igre i aplikacije), pogodno za edukaciju korisnika, kojim se upravlja Multi-Touch-zaslonom osjetljivim na dodir prsta. Do danas je organizirano osamdesetak raznih $i P a d$-radionica ${ }^{15}$ na kojima je sudjelovalo oko 890 polaznika te 36 iPad foto-radionica s više od petsto polaznika. iPad-aplikacija ScratchJr ${ }^{16}$ kao

\footnotetext{
10 Više o makerspace- $u$ vidi na What is a makerspace? [citirano:2018-05-24]. Dostupno na: www.makerspaces.com/what-is-a-makerspace.

11 Gradska knjižnica Zadar 2012.: godišnje izvješće / urednik Mladen Masar. Zadar: Gradska knjižnica, 2012. Str. 36. [citirano: 2017-25-11]. Dostupno i na: http://www.gkzd.hr/sites/default/ files/gi_2012_w.pdf.

12 Belevski, M. Američki kutak Zadar. // Knjižnica komunikacijsko i multikulturalno središte lokalne zajednice : zbornik radova / priredila za tisak Jelica Leščić. Zagreb: Nacionalna i sveučilišna knjižnica, 2012. Str. 331-336.

13 Usp. IFLA-ine smjernice za knjižnične usluge i mladež. Nav. dj., str. 11-27.

14 Engl. pojam STEM akronim je početnih slova četiriju područja: Science, Technology, Engineering i Mathematics (znanost, tehnologija, inženjerstvo i matematika). Usp. Božić, I. Evo što znači i koja područja obuhvaća STEM. [citirano: 2017-20-11]. Dostupno na: www.srednja.hr/ zbornica/nastava/evo-sto-znaci-i-koja-podrucja-obuhvaca-stem/.

15 Usp. iPad radionica. // Gradska knjižnica Zadar. [citirano: 2018-05-24]. Dostupno na: www. gkzd.hr/tagovi/ipad-radionica.

16 Besplatno dostupna na ScratchJr: coding for young children.[citirano:2018-05-24]. Dostupno na: http://www.scratchjr.org/.
} 
uvodni programski jezik pogodna je priprema za grafičko programiranje u robotici.

Osim u Knjižnici i njezinim ograncima, iPad-programi i aktivnosti realiziraju se i u suradnji s odgojno-obrazovnim ustanovama i ustanovama u kulturi ${ }^{17}$ (osnovne i srednje škole, vrtići, školske i narodne knjižnice). Putem bibliobusne službe Knjižnice u suradnji sa školskim knjižničarima ${ }^{18}$ te učiteljima i nastavnicima razvija se suradnja i na širem području Zadra (otoci i zaleđe).

Američki kutak Gradske knjižnice Zadar, u suradnji sa školskim knjižničarima, nastavnicima i izdavačkim kućama (Školska knjiga i Profil Klett) 2016. godine organizira program iPad i u našoj školi-iPad in Our School. ${ }^{19} \mathrm{U}$ osnovnim školama u Stankovcima i Lišanima Ostrovičkim nedaleko Zadra u dvotjednoj nastavi korišteni su iPad-uređaji, edukativne aplikacije i digitalni udžbenici, s ciljem osvještavanja i primjene novih tehnologija.

U organizaciji ogranka Knjižnice Bili brig povodom Mjeseca hrvatske knjige organizirana je radionica pod nazivom Solarni automobil, na kojoj je prezentirana i uporaba 3D-printera. Radionicu su održali 11. studenoga 2016. godine učenici Strukovne škole Vice Vlatković za učenike osnovne škole Zadarski otoci u Zadru. Ta radionica potaknula je knjižničare Gradske knjižnice Zadar na nastavak suradnje i osmišljavanje edukativnog STEM-programa GENERATOR.

Od osnivanja Američkog kutka Zadar 2005. godine do danas, nabavom građe i opreme za potrebe programa i aktivnosti kutka, osim razne računalne opreme (stolna i prijenosna računala, iPad-uređaji), audio-vizualne opreme (digitalna videokonferencija, 3D-televizija, CD, DVD i 3D Blu-ray Disc-uređaji za reprodukciju), nabavljena je i raznovrsna oprema za igranje virtualnih računalnih igara: Wii Nintendo, Microsoft X-Box 360 i konzole Sony PlayStation 4 te oprema Sony PlayStation VR (Virtual Reality). ${ }^{20}$ VR ili virtualna stvarnost računalna je simulacija u kojoj korisnik koristeći potrebnu računalnu opremu (npr. promatranje pomoću kacige sa zaslonima) ima iluziju pripadanja (nalazi se u) virtualnoj okolini.

17 Ta outreach praksa razvija se već dugi niz godina. Vidi i Flowers, S. Young adults deserve the best: YALSA's competencies in action. Chicago : American Library Association, 2011. Str. 27-36.

18 Usp. IFLA-ine i UNESCO-ove smjernice za školske knjižnice. Zagreb : Hrvatsko knjižničarsko društvo, 2004. Str. 19-23.

19 Vidi više: Belevski, M.; S. Segarić. iPad i u našoj školi - iPad in Our School. // Stručni skup Dječja knjižnica, danas i njezina odgojno obrazovna dimenzija : zbornik radova / uredili Marina Šimić i Vilijam Lakić. Šibenik : Gradska Knjižnica Juraj Šižgorić, 2017. Str. 61-76.

20 Više o interaktivnoj 3D-grafici Virtual Reality i njezinim primjenama: Pandžić, I. S. Virtualna okruženja: računalna grafika u stvarnom vremenu i njene primjene. Zagreb: Element, 2004. Str. 2-15. 
Početkom 2016. godine donacijom Američkog veleposlanstva u Zagrebu kao dijelom potpore STEM-programima ${ }^{21}$ za Američke kutke u Hrvatskoj ${ }^{22}$ nabavljena je oprema za 3D-modeliranje i printanje (3D-printer, 3D-skener i 3D-olovka) te inicijalna oprema za osmišljavanje edukativnog programa na području robotike, po uzoru na projekt udruge Institut za razvoj $i$ inovativnost mladih (IRIM) pod nazivom Croatian Makers liga (http://croatianmakers.hr). Taj projekt iz robotike provodi se u hrvatskim osnovnim školama od 2014. godine s ciljem razvoja digitalne i znanstvene pismenosti, tehnoloških i ostalih kompetencija u okviru STEM-područja.

U Hrvatskoj djeluje niz klubova robotike u sklopu Hrvatskog robotičkog saveza i Hrvatske zajednice tehničke kulture (www.hztk.hr/hrvatsko-drustvo-za-robotiku). Postoje i druge inicijative aktivne na STEM-području: Udruga Robofreak (www.robofreak.hr/index.php/robotika), Osijek Software City Robocode (http://softwarecity.hr/projekt/robocode/), MIS Strahoninec roboti$k a$ (http://www.udruga-mis.hr/programiranje-i-robotika/), Robokacija (www. robokacija.hr), Korak do znanosti - STEaM za djecu (http://korakdoznanosti. com), Udruga Gradionica (www.gradionica.hr), Udruga Inovatic (http://udruga-inovatic.hr/), Udruga za robotiku Futura (http://udruga-futura.hr/) i drugi. Od ljeta 2016. godine djelatnici Mediateke i Američkog kutka Zadar kao novost u ponudi organiziraju edukativne STEM-radionice Kako radi $3 D$-printer? namijenjene djeci i mladima. U suradnji s Dječjim odjelom povodom organizacije programa Tjedan dinosaura, Tjedan Maca papučarica i Tjedan Paddington (čitanje priča, filmovi iznenađenja, radionice iPad Recolor ${ }^{23}$ ) prigodno su organizirane i 3D-printer-radionice (demonstracija uređaja, printanje 3D-modela tematskih likova: dinosaur, Maca papučarica, Medo Paddington).

\footnotetext{
21 Vidi više o partnerstvu, potpori, planiranju, organizaciji i uvođenju STEM-programa u knjižnice: STEM (Science, Technology, Engineering, Mathematics) Programming. [citirano: 201822-03]. Dostupno na: https://youthserviceslibrarianship.wikispaces.com/STEM+\%28Science\%$2 \mathrm{C}+$ Technology $\% 2 \mathrm{C}+$ Engineering\% $2 \mathrm{C}+$ Mathematics $\% 29+$ Programming ; također: Shtivelband, A; L. Riendeau; A. Wallander-Roberts; R. Jakubowski. Implementing effective STEM programming in public libraries : eight recommendations : report to Space Science Institute's National Center for Interactive Learning. 2016. [citirano: 2018-22-03]. Dostupno na: http://www.nc4il. org/images/papers/Research-White-Paper-121216.pdf ; također: STEAM programming toolkit : science, technology, engineering, arts \& math. YALSA, 2016. [citirano: 2018-22-03]. Dostupno na: http://www.ala.org/yalsa/sites/ala.org.yalsa/files/content/2016STEAM\%20TOOLKIT.pdf.

22 Usp. Lončar, M.; I. Klak Mršić. Američki kutak Zagreb: pogled unatrag, pogled unaprijed. // HKD Novosti 73(2017). [citirano: 2017-9-11]. Dostupno na: https://www.hkdrustvo.hr/hkdnovosti/clanak/1350.

${ }^{23} i$ Pad-aplikacija namijenjena djeci predškolske dobi i nižih razreda osnovne škole pogodna za kreiranje e-bojanke pomoću digitalne fotografije.
} 
U međuvremenu pojavila se potreba za osmišljavanjem kompleksnijeg edukativnog STEM-programa ${ }^{24}$ za djecu i mlade. S obzirom na to da djelatnici Mediateke i Američkog kutka do tada nisu imali dovoljno znanja i iskustva u 3D-modeliranju, uz pomoć nastavnika i učenika Strukovne škole Vice Vlatković u Zadru, nakon više zajedničkih radnih sastanaka i razmjene iskustava, knjižničari se osposobljavaju i usvajaju nova znanja na području 3D-printanja i robotike.

U organizaciji Američkog kutka i Mediateke Gradske knjižnice Zadar tijekom 2016. i 2017. godine organizirano je ukupno 58 radionica iz područja STEM-programa u kojima je sudjelovalo više od 650 djece i mladih (slika 1). Organizirano je i šest ciklusa programa GENERATOR (ukupno 24 radionice) u kojem je sudjelovalo sedamdesetak polaznika.

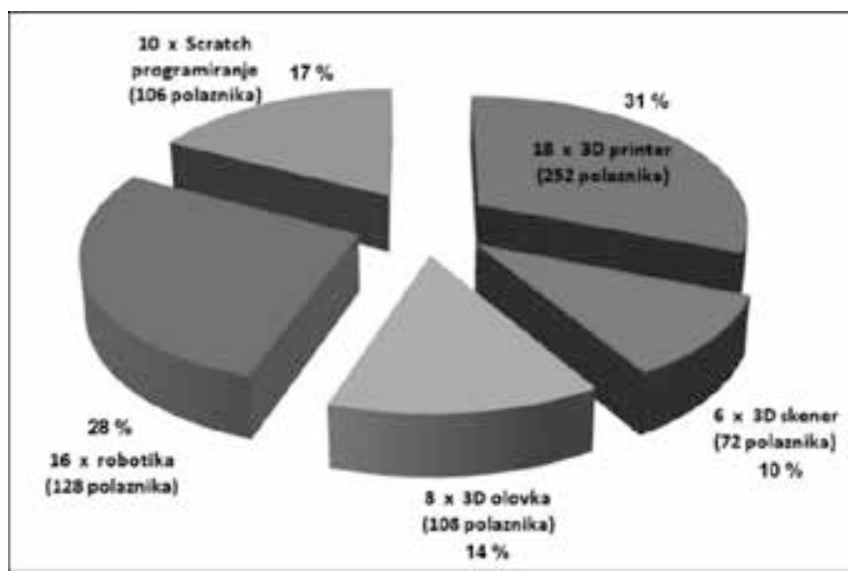

Slika 1. Statistika STEM-programa

\section{STEM-program GENERATOR: radionice na struju}

U današnje vrijeme sve bržeg tehnološkog razvoja edukativni STEM-programi posebno su zanimljivi djeci i mladima. Pojam STEM obuhvaća razne interdisciplinarne grane. U Sjedinjenim Američkim Državama izučava se čitav niz STEM-područja: fizika, kemija, biologija, matematika, primijenjena matematika, statistika, računalstvo, računalna znanost, psihologija, biokemija, robotika, raču-

24 Vidi više o edukaciji i STEM-programima u narodnim knjižnicama: Hakala, J.S.; K. MacCarthy; C. Dewaele; M. Wells; P. B. Dusenbery; K. LaConte. STEM in public libraries : national survey results. 2016. Str. 16-18. [citirano: 2018-22-03]. Dostupno na: http://www.nc4il.org/ images/papers/FINAL_STEM_LibrarySurveyReport.pdf ; također: Dusenbery, P. B. The STEM education movement in public libraries. // Informal Learning Review 124(2014), 14-19. [citirano: 2018-22-03]. Dostupno na: https://www.lpi.usra.edu/education/stemlibraryconference/events/ ILR_STEM_Library_Paper.pdf. 
nalno inženjerstvo, elektrotehnika, elektronika, strojarstvo, industrijsko inženjerstvo, građevinarstvo, kemijsko inženjerstvo, astrofizika, astronomija, optika, nanotehnologija, nuklearna fizika, matematička biologija, operacijska istraživanja, neurobiologija, biomehanika, bioinformatika, akustički inženjering, geografski informacijski sustavi, atmosferske znanosti i drugo, dok se u Hrvatskoj neka od navedenih STEM-područja uopće ne izučavaju. ${ }^{25}$

Ideja STEM-obrazovanja temelji se na jedinstvenom, integriranom obliku učenja četiriju specifičnih disciplina: znanosti, tehnologije, inženjerstva i matemati$\mathrm{ke}^{26}$

U svakodnevnom životu često se susrećemo s radom u STEM-području. Znanstvenim proučavanjem dolazimo do novih saznanja i razumijevanja svijeta oko nas, kojeg smo i sami dio (npr. voda, zemlja, vrijeme, životinjski svijet, astrologija, sunce itd.). Neizostavan su dio svakodnevnice i tehnologija, tehnološke inovacije (npr. teleskop, mikroskop, današnja računala, pametni telefoni i drugo) te dizajniranje novih stvari (npr. razni proizvodi, ceste, mostovi, zgrade, ekološki uređaji i sustavi i drugo), kao i matematika, najvažniji dio STEM-programa na koji se neizostavno oslanjaju ostale tri discipline. Primjenjujemo ju s razumijevanjem i olakšavamo si život (npr. trgovina, bankarstvo, investicije itd.).

Djeca i mladi prirodno su radoznali i stalno eksperimentiraju. Kroz STEM-programe moguće je stvoriti okruženje te poticati djecu i mlade ${ }^{27}$ da kroz igru istražuju, pronalaze odgovore i prihvaćaju različitost u razmišljanju i rješavanju zadanih problema.

Kao logičan slijed i posljedica ranije spomenute suradnje s nastavnicima i učenicima Strukovne škole Vice Vlatković u Zadru, osmišljen je STEM-program pod nazivom GENERATOR: radionice na struju ${ }^{28}$ (slika 2). Organiziran je i izvodi se u ciklusu od četiri interaktivne radionice koje traju po dva školska sata:

- 3D-printer XYZ DaVinci 1.1 Plus

- 3D-skener, 3D-olovka i iPad

- robotika 1: $m$ Bot V1.1

- robotika 2: LEGO Mindstorms EV3.

\footnotetext{
25 Usp. Božić, I. Nav. dj.

26 Usp. STEM obrazovanje - od predškolarca do studenta. [citirano: 2017-20-11]. Dostupno na: www.maligenijalci.com/stem-obrazovanje-od-predskolarca-studenta.

27 Vidi više o metodama, poticaju, usmjeravanju i motivaciji tijekom preovedbe STEM-programa u narodnim knjižnicama: Baek, J. Y. Public libraries as places for STEM Learning: an exploratory interview study with eight librarians: education/research report. Boulder, Co.: National Center for Interactive Learning, 2013. Str. 4-11. [citirano: 2018-22-03]. Dostupno na: http://www.nc4il.org/ images/papers/Baek_Public\%20Libraries\%20as\%20Places\%20for\%20STEM\%20Learning.pdf.

28 Gradska knjižnica Zadar. Generator. [citirano: 2017-25-11]. Dostupno na: www.gkzd.hr/content/generator-1.
} 


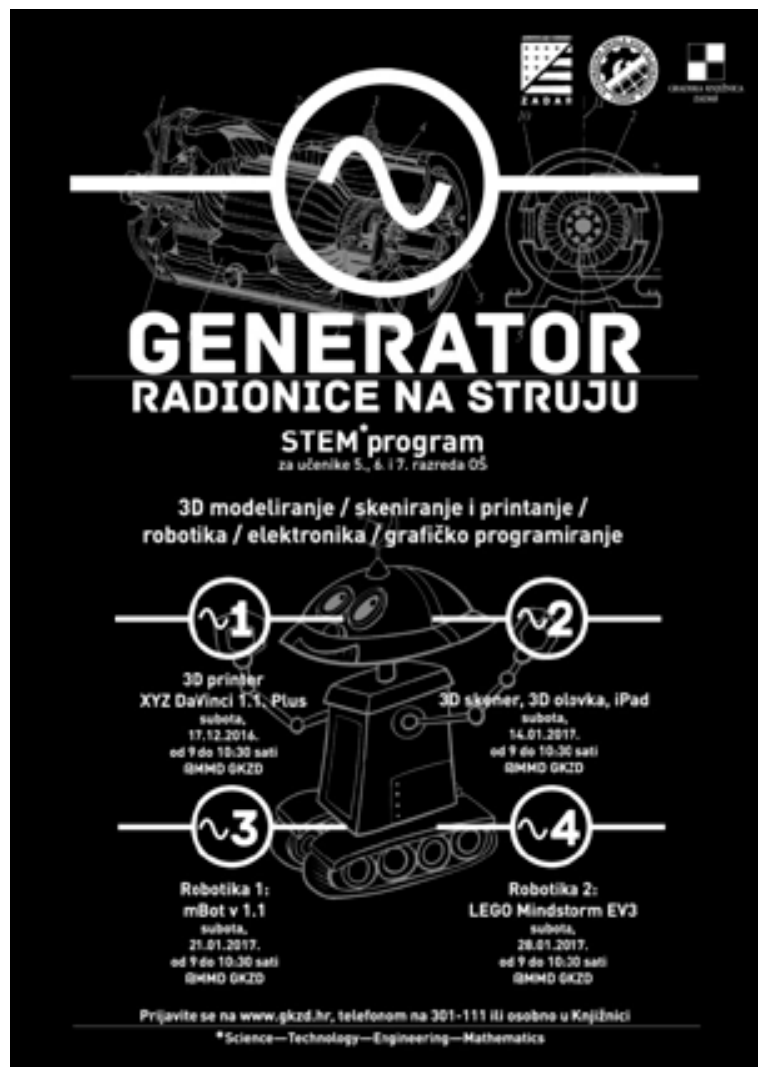

Slika 2. Plakat GENERATOR: radionice na struju

Radionice su namijenjene učenicima 5., 6. i 7. razreda osnovnih škola. U praksi roditelji često prijavljuju djecu, učenike nižih razreda osnovnih škola, a javlja se interes i kod srednjoškolaca. Knjižničari izlaze ususret zahtjevima te se prema potrebi program STEM-edukacije prilagođava. Voditelj programa je djelatnik Gradske knjižnice Zadar Milko Belevski, u suradnji s učenicima četvrtog razreda Strukovne škole Vice Vlatković u Zadru ${ }^{29}$ Jakovom Šušberićem i Josipom Lazićem. Njih dvojica osigurali su nastup na otvorenom kupu Hrvatske WER-u (World Educational Robot Contest, rujan, 2017.), međunarodnom natjecanju iz edukacijske robotike održanom u Zagrebu, a zatim su sudjelovali na svjetskom natjecanju u Šangaju u svom uzrastu u studenome 2017. godine.

29 Vidi više: Učenici Strukovne škole Vice Vlatković pobjedom u Zagrebu osigurali nastup u Šangaju. [citirano: 2017-12-11]. Dostupno na: https:/ezadar.rtl.hr/dogadaji/2726181/ucenici-strukove-skole-vice-vlatkovic-pobjedom-u-zagrebu-osigurali-nastup-u-sangaju/. 
Program GENERATOR zamišljen je na takav način da stariji učenici srednjih škola kao mentori prenose svoja znanja i iskustva učenicima osnovnih škola, razvijaju komunikacijske vještine i promoviraju svoju školu. Završetkom programa polaznici stječu osnovna znanja o tome kako rade 3D-printer i 3D-skener, kako koristiti 3D-olovku, kako koristiti iPad 3D-aplikacije, te se i sami okušavaju u 3D-printanju i 3D-modeliranju. Program robotike obuhvaća sastavljanje robotskih setova $\mathrm{mBot} V 1.1$ i LEGO Mindstorm EV3 te učenje grafičkog programiranja, elektronike i osnova robotike.

Cilj tog edukativnog STEM-programa jest edukacija, poticanje na kreativan rad, usmjeravanje i osvještavanje o mogućnostima primjene novih tehnologija kroz niz kreativnih i interaktivnih radionica, kao i pobuđivanje interesa mladih generacija za odabir zanimanja prilikom daljnjeg školovanja i njihovo uvođenje u budući svijet poduzetništva i rada. Koliko je STEM-obrazovanje danas važno, pokazuje podatak s mrežne stranice www.STEMcoonnector.org o potrebi za 8,65 milijuna radnika u svijetu s područja STEM-poslova do 2018. godine. ${ }^{30}$

\subsection{Organizacija i tehnički zahtjevi programa}

Zainteresirani polaznici, uz suglasnost roditelja, prijavljuju se u program GENERATOR putem prijava na mrežnim stranicama Knjižnice (www.gkzd.hr/content/generator-1) ili telefonski. Nakon prijave sudionika knjižničari u osobnom kontaktu informiraju roditelje o načinu provođenja programa. Uz usmeno odobrenje roditelja provedena je anketa o zadovoljstvu korisnika koja je analizirana kasnije u radu. Rad u grupama obuhvaća najviše dvanaest sudionika s kojima rade najmanje dva mentora. Program se izvodi u prostoru knjižnične multimedijske dvorane koja se prenamjenjuje u odgovarajući radni prostor za svaku radionicu posebno. Organiziranjem kulturno-animacijskih aktivnosti knjižničari Gradske knjižnice Zadar suočili su se s raznim prostornim i tehničkim zahtjevima. Tako i organizacija STEM-programa zahtijeva posebne uvjete: rezervaciju multimedijske dvorane i njezinu prenamjenu uz sudjelovanje tehničkog osoblja (prijenos STEM-opreme, stolova i stolica, čišćenje prostora).

Osim pripadajuće STEM-opreme (slika 3), za svaku radionicu potrebno je osigurati računalne i audio-vizualne uvjete za rad: prijenosna računala, bežični internet, projektor, platno za projekciju i zvučni razglas za edukaciju i prikazivanje mrežno dostupnih tutoriala ${ }^{31}$ kao praktičnih primjera kreativnosti i primjene znanja na području 3D-modeliranja i robotike.

\footnotetext{
30 Usp. STEM-obrazovanje. Nav. dj.

31 Engl. tutorial - priručnik, vodič za podučavanje. Vidi: Kiš, M. Englesko-hrvatski informatički rječnik. Zagreb: Naklada Ljevak, 2000. Str. 932.
} 


\begin{tabular}{|c|c|c|c|}
\hline GENERATOR" oprema & kolizina & proizwodač & dobavljač \\
\hline računalo (Intel is procesor, 8GB RAM-a) & 1 & Do izbory & \\
\hline projektor & 1 & po izboru & \\
\hline ipad tablet racunalo & 10 & www.apple.com & www.apple.com/hr \\
\hline 30 printer $X Y Z$ DaVinci 1.1 Plus & 1 & www.xyzprinting.com & www.123print.hr \\
\hline 3D olowkaVelleman & 8 & www.velleman.eu & www-ad-electronic.hr \\
\hline 3D olowka Forever & 3 & www.forever.eu & www.links.hr/hr \\
\hline filament niti ( $3 \mathrm{D}$ printer, $3 \mathrm{D}$ olowka) razne boje & 12 & www.xyzprinting.com & www.123print.hr \\
\hline 30 skener $\mathrm{XYZ}$ printing & 1 & www.xyzprinting.com & www.123print.hr \\
\hline mBot v1.1 edukacijski robot & 10 & www.makeblock.com & www-arduino-elektronika.eu \\
\hline LEGO Mindsotrms EV3 edukacijski robot & 3 & www.lego.com & www_arduino-elektronika.eu \\
\hline \multicolumn{4}{|l|}{ „GENERATOR" dodatna oprema } \\
\hline Makeblock mDrawBot Kit (groficko crtonje) & 1 & www.makeblock.com & www.arduino-elektronika.eu \\
\hline Makeblock LaserBot (lasersko grovironje) & 1 & www.makeblock.com & www_arduino-elektronika.eu \\
\hline Makeblock Ultimate 2.0 Robot Kit & 1 & www.makeblock.com & www.arduino-elektronika.eu \\
\hline Airblock The Modular Programmable Dron & 2 & www.makeblock.com & www.arduino-elektronika.eu \\
\hline Codeybot LED Laser Programmable Robot & 4 & www.codeybot.com & www_arduino-elektronika_eu \\
\hline
\end{tabular}

Slika 3. Popis opreme namijenjene programu GENERATOR

U praksi, kao i iz iskustva djelatnika Knjižnice u radu s djecom, najpoželjniji termin za organiziranje kreativnih edukativnih radionica u Gradskoj knjižnici Zadar jest subota ujutro. S obzirom na profil sudionika (djeca i mladi) i važnost timskog rada, termini tijekom školskog tjedna nisu pogodni zbog različitih školskih smjena te čestih izvannastavnih obveza djece i mladih (sportske, kulturno-umjetničke aktivnosti, škole stranih jezika i sl.).

\subsection{Radionica 3D-printer XYZ DaVinci 1.1 Plus}

Na prvoj radionici 3D-printer XYZ DaVinci 1.1 Plus $^{32}$ (slika 4) u ciklusu GENERATOR polaznici stječu znanja o tome što je 3D-printer i kako radi. Princip rada 3D-printera vrlo je jednostavan: grijači zagrijavaju materijal za printanje (duga savitljiva plastična nit ili filament standardne debljine 1,75 $\mathrm{mm}$ ) na temperaturu $160-250^{\circ} \mathrm{C}$ te se on u tekućem stanju kroz mlaznicu (ekstruder) brizga na grijanu podlogu. Hlađenjem nastaje 3D-model maksimalne veličine $20 \mathrm{~cm}$ x $20 \mathrm{~cm}$ x $20 \mathrm{~cm} \cdot{ }^{33}$ Neki od modela 3D-printera dostupnih na tržištu jesu: Rostock Mini (www.thingiverse.com/thing:32850), Velleman $K 8200$ (www.velleman.eu/products/view/?id=412554), BQ Witbox ( www. bq.com/en/witbox-2), Ultimaker 2+ (https:/ultimaker.com/en/products/ultimaker-2-plus), Makerbot Replicator + (www.makerbot.com/replicator/),

32 Da Vinci 1.1 Plus. [citirano: 2017-14-11]. Dostupno na: www.xyzprinting.com/en-GB/product/da-vinci-1-1plus.

33 Vidi više: XYZprinting da Vinci 1.1 Plus User Manual. [citirano: 2018-15-04]. Dostupno na: https://www.manualslib.com/manual/1034975/Xyz-Printing-Da-Vinci-1-1-Plus.html. 
Leapfrog Creatr HS (www.lpfrg.com/en/creatr-hs/), Goya 3D GOGO (www. goya3d.com/), Mbot 3D Grid 2 (www.mbot3d.com/product-3d-printer/mbotgrid-ii-plus).

Polaznici stječu znanja o mogućnostima 3D-printera i njihovoj primjeni (medicina, industrija, građevina, arhitektura, virtualna stvarnost, navigacija, robotika, znanstvena istraživanja, kreativan rad, zabava itd.), saznaju koji su im sastavni dijelovi, na koji ih se način održava i čisti, kako se kalibrira ${ }^{34}$ 3D-printer te koje se vrste materijala koriste za printanje.

Za 3D-printanje koriste se dvije vrste materijala: ABS- i PLA-filament. ABS (akrilonitril butadien stiren) ${ }^{35}$ je filament na bazi nafte. Tvrd je i otporan na udarce. Temperatura taljenja mu je $210-250^{\circ} \mathrm{C}$. PLA (polilaktid) ${ }^{36}$ je biorazgradivi filament dobiven iz obnovljivih izvora (kukuruzni ili krumpirov škrob, šećerna trska). Ekološki je prihvatljiviji materijal u usporedbi s ABS-om. Temperatura taljenja $\mathrm{mu}$ je $185-230^{\circ} \mathrm{C}$. ABS- i PLA-filamenti dobro prianjaju na čistu grijanu podlogu 3D-printera ili na podlogu s nanesenim ljepilom za papir.

Polaznici doznaju više informacija i o tome gdje na mrežnim stranicama mogu pronaći upute za korištenje 3D-printera XYZ DaVinci 1.1 Plus, besplatne računalne programe za 3D-modeliranje, galerije s gotovim mrežno dostupnim 3D-modelima za printanje, informacije o načinima 3D-modeliranja (računalno modeliranje, crtanje, geometrijska transformacija, fotografija, skeniranje). Upoznaju se s osnovama rada u programu za 3D-modeliranje XYZmaker ${ }^{37}$ (kreiranje, oblikovanje i dizajniranje 3D-modela) i programu za printanje 3D-modela $X Y Z$ ware $^{38}$ (postupci i namještanje osnovnih i naprednih postavki, brzina printanja, pozicioniranje u prostoru printera, ispuna ili gustoća printanja, kloniranje modela, dimenzioniranje parametara visine, širine i dubine 3D-modela, printanje gotovog 3D-modela, kreiranje i printanje vlastitog 3D-modela i drugo) te stječu saznanja o drugim računalnim programima namijenjenim 3D-modeliranju i printanju.

\footnotetext{
34 Engl. calibration - podešavanje, ugađanje, podešavanje točnosti mjernog instrumenta, provjeravanje podešenosti. Vidi: Kiš, M. Nav. dj. Str. 162.

35 Vidi i Acrylonitrile Butadiene Styrene (ABS). // Techopedia. [citirano: 2017-14-11]. Dostupno na: https://www.techopedia.com/definition/29375/acrylonitrile-butadiene-styrene-abs.

36 Vidi i Polylactic Acid (PLA). // Techopedia. [citirano: 2017-14-11]. Dostupno na: https:// www.techopedia.com/definition/29379/polylactic-acid-pla.

37 Besplatno dostupan na XYZmaker 1.0. [citirano:2018-05-24]. Dostupno na: www.xyzprinting.com/en-GB/software/xyzmaker.

38 Besplatno dostupan na XYZware: [citirano:2018-05-24]. Dostupno na: www.xyzprinting. com/en-GB/software/xyzware.
} 


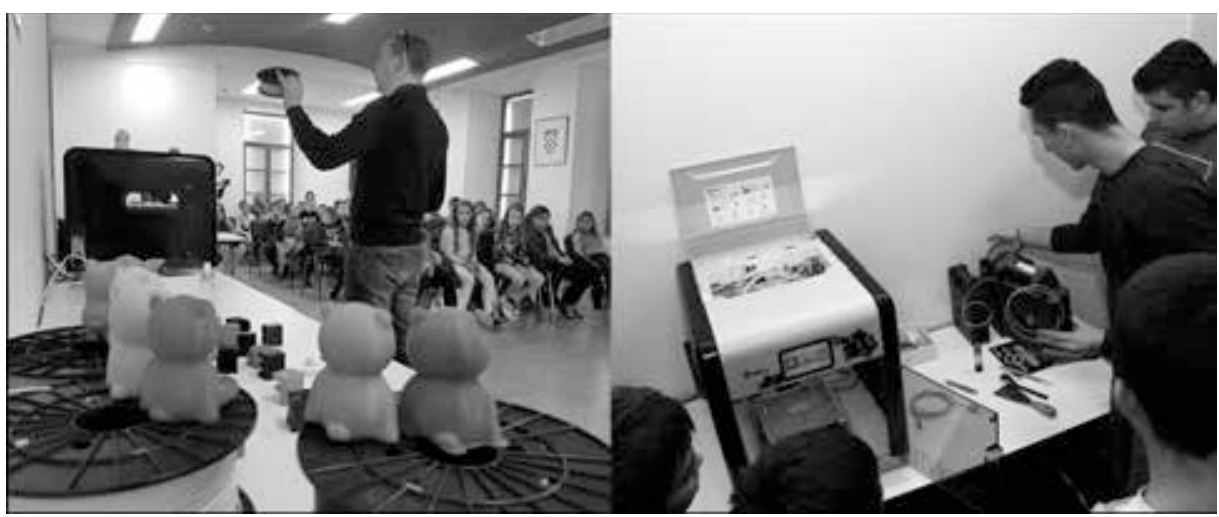

Slika 4. Radionica 3D-printer

Faze kreiranja i izrade 3D-modela jesu sljedeće: izrada CAD-modela (Computer-Aided Design Model $^{39}$, računalno oblikovan, projektiran, dizajniran 3D-model), pretvaranje CAD-modela u STL-datoteku (Standard Tessellation Langua$g e^{40}$, format za printanje 3D-modela koji je od 1987. tvrtka 3D Systems uvela kao standard: www.3dsystems.com), učitavanje STL-datoteke u 3D-printer, podešavanje parametara 3D-printera, proces printanja 3D-modela (Fused Filament Fabrication, metoda slojevitog nanošenja rastaljenog filamenta, standardnog promjera 1,75 mm, koji se istiskuje kroz mlaznicu ili ekstruder i slaže sloj po sloj na radnu podlogu 3D-printera dok ne nastane $3 \mathrm{D}$-model) ${ }^{41}$, naknadna obrada 3D-modela (ako je potrebno) i uporaba 3D-modela.

3D-printer XYZ DaVinci 1.1 Plus omogućuje printanje 3D-modela samo u jednoj boji. Kvaliteta ovisi o visini i debljini printanog sloja (najčešće oko 75 mikrometara, tanje od lista papira). Fina površina dobiva se brušenjem ili tretiranjem acetonom s kojim je moguće i lijepljenje glatkih površina. ${ }^{42}$

\subsection{Radionica 3D-olovka, 3D-skener i iPad}

Druga radionica sastoji se od tri dijela: 3D-olovka (slika 5), 3D-skener i korištenje iPad-aplikacija (slika 6) za 3D-modeliranje i grafičko programiranje.

\footnotetext{
39 Kiš, M. Nav. dj., str: 216. Vidi i Computer-aided design model. [citirano: 2017-14-11]. Dostupno na: https://www.techopedia.com/definition/2063/computer-aided-design-cad.

40 STL (Standard Triangle/Tessellation Language) reader/writer. [citirano: 2017-7-11]. Dostupno na: https://docs.safe.com/fme/html/FME_Desktop_Documentation/FME_ReadersWriters/stl/ stl.htm.

41 Vidi više: Fused Filament Fabrication (FFF). // Techopedia. [citirano: 2017-14-11]. Dostupno na: https://www.techopedia.com/definition/29377/fused-filament-fabrication-fff.

${ }^{42}$ Vidi više: XYZprinting. Nav. dj.
} 


\subsubsection{D-olovka}

3D-olovka uređaj je koji na maštovit, jednostavan i lak način omogućuje ispisivanje trodimenzionalnih objekata u prostoru na istom principu kao 3D-printeri, ali ručno, bez računala i računalnog programa za dizajniranje. Ergonomski je dizajnirana i lagana. 3D-olovke sve su popularnije i potiču kreativnost kod mlađe populacije, a izazov su i u umjetničkom izražavanju. Osim kroz razmjenu iskustava, sudionici tijekom radionice stječu saznanja i putem mrežno dostupnih edukativnih primjera o načinu funkcioniranja i korištenja 3D-olovke, njezinim tehničkim osobinama, promjeni filamenta i boje te čišćenju i održavanju 3D-olovke.

Kod 3D-olovke grijač i mlaznica nalaze se u jednom kućištu, a moguće je regulirati brzinu ispisa. Kao i kod 3D-printera, koriste se ABS- i PLA-filamenti debljine $1,75 \mathrm{~mm}$. Princip rada uređaja vrlo je sličan: filament se zagrijava na temperaturi $160-250^{\circ} \mathrm{C}$ i prelazi u tekuće stanje te se kroz mlaznicu brizga na podlogu, a hlađenjem nastaje $3 \mathrm{D}$-struktura.

U praktičnom dijelu sudionici samostalno kreiraju 3D-modele 3D-olovkom na tri načina: izradom proizvoljnih 3D-oblika na čvrstoj podlozi (npr. izrada osobnih imena), kreiranjem pomoću unaprijed pripremljenih šablona (npr. izrada poznatih dječjih likova iz crtanih filmova) ili izradom i spajanjem više šablonskih dijelova u jedan model (npr. izrada kućice, naočala, leptira i dr.).

Neki od tipova 3D-olovki dostupnih na tržištu jesu: Velleman 3D Pen (www. velleman.eu/products/view/?id=420418), DaVinci 3D Pen (http://eu.xyzprinting.com/eu_en/Product/3D-Pen), Forever Idea Printing 3D Pen (www.forever. eu/fun-line/3d-pens), Lix 3D Smart Pen (http://lixpen.com), 3Doodler 3d Printing Pen (https://the3doodler.com) i CreoPop 3D Printing Pen (https://creopop. com).



Slika 5. Radionica 3D-olovka 


\subsubsection{D-skener XYZprinting}

Ručni 3D-skener XYZprinting s ugrađenom kamerom Intel RealSense $e^{43}$ omogućava korisnicima skeniranje 3D-objekata u boji bilo kojeg oblika ili veličine. Skener radi na način da kombinira infracrveno zračenje, CCD-uređaj (Charge-Coupled Device $)^{44}$ i podatke za unos boje koji zajedno stvaraju jednu sliku, a može snimiti do 30 slika u sekundi. Može se priključiti na računalo putem USB-utora (Plug In Play) i funkcionira na bilo kojem računalu s minimalnim tehničkim zahtjevima: operativni sustav Windows 8.1 te računalni procesor pete generacije CPU Intel $15 .{ }^{45}$

Sudionici se okušavaju u tri osnovna načina skeniranja: skeniranje glave, tijela i objekta (za skeniranje tijela i objekta koristi se Body Mode). Nakon skeniranja 3D-model se može pregledati, popraviti ili dodatno obraditi u računalnom programu XYZscan Handy ${ }^{46}$ (uređivanje boje, brisanje dijelova modela i drugo). $\mathrm{Na}$ radionici se demonstrira rad s dva modela 3D-skenera: XYZprinting 3D Scanner ${ }^{47}$ i Sense $3 D$ Scanner. ${ }^{48} 3 \mathrm{D}$-skener pomiče se sporo i ravnomjerno u svim smjerovima na udaljenosti od 0,5 do $0,7 \mathrm{~m}$ od objekta. Maksimalna veličina skeniranja je $100 \mathrm{~cm} \times 100 \mathrm{~cm} \times 200 \mathrm{~cm}$. Okretanjem objekta na okretnoj stolici, dok je skener učvršćen na stalku, postiže se veća kvaliteta skeniranja.

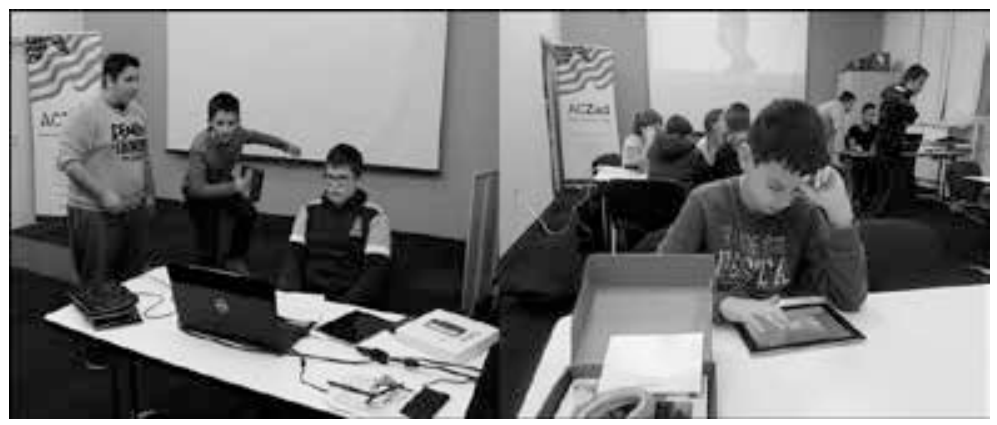

Slika 6. Radionica 3D-skener i iPad

\footnotetext{
43 Vidi više: Intel realsense technology : observe the world in 3D. [citirano: 2017-10-11]. Dostupno na: www.intel.com/content/www/us/en/architecture-and-technology/realsense-overview.html.

${ }^{44}$ CCD Eng. Charge-Coupled Device - sklop s prijenosom naboja, vrpca sa svjetlosno osjetljivim ćelijama koja svjetlosne valove pretvara u digitalne podatke. CCD-senzori danas se najčešće koriste u digitalnim fotoaparatima i kamerama. Vidi: Kiš, M. Nav. dj., str.180.

45 CPU Eng. Central Processing Unit - središnja računalna jedinica za obradu, središnji procesor. Vidi: Kiš, M. Nav. dj., str. 174.

46 Usp. XYZscan handy. [citirano:2018-05-24]. Dostupno na: https://www2.xyzprinting.com/ en-GB/software/xyzscan-handy.

47 Više o modelu na XYLZprinting 3D: scanner 1.0A. [citirano:2018-05-24]. Dostupno na: www.xyzprinting.com/en-GB/product/3d-scanner-pro.

48 Više o modelu na Sense: 3D scanner. [citirano:2018-05-24]. Dostupno na: www.3dsystems. com/shop/sense.
} 


\subsection{3. iPad}

Tijekom druge radionice polaznici imaju mogućnost upoznavanja i korištenja iPad-aplikacija za 3D-modeliranje i printanje (Sculpt + , Tinkerplay, Maker Bot, CreatureS, 123D Make, 123D Haus, 123D Design, 123D Catch, 123D Sculpt, XYZgalery, XYZrobo, XYZView, i3D Viewer, Solid Craftm 3DC, Cubity Draw, $3 d$ Builder) te $i$ Padovih računalnih igrica za programiranje robotskog kretanja i svladavanje prostornih prepreka kao pripreme za radionice iz robotike (Lightbot Hour, Robot School, Tynker, Bloxy World, Wonder, Kids , n' Code).

\subsection{Radionica Robotika 1: mBot v1.1}

Na trećoj radionici (slika 7), kao uvod u svijet robotike, elektronike i grafičkog programiranja, polaznici se susreću s edukacijskim robotskim setom mBot v1.1 $1^{49}$ koji je razvijen u suradnji tvrtki Makeblock ${ }^{50}$ i Arduino $^{51}$, a inspiriran je računalnim grafičkim programom Scratch $2.0^{52}$ koji se može bežično povezati s uređajem $m$ Bot v1.1 koristeći Bluetooth ${ }^{53}$ ili modulom $2.4 \mathrm{GHz}$ Wireless. ${ }^{54}$ Set pruža neograničene mogućnosti djeci i mladima za usvajanje znanja u STEM-području, odnosno izvanredno je rješenje za stjecanje praktičnog iskustva u programiranju, elektronici i robotici. Sadrži 38 sastavnih dijelova (računalni, mehanički, elektronski, senzori, kabeli, napajanje) koji se mogu složiti u desetak minuta. Računalni program $m B l o c k^{55}$ pomoću grafičkih blokova prema načelu ,povuci i ispusti““ omogućuje djeci brzo učenje osnova grafičkog programiranja, kontroliranja robota i korištenje više funkcija koje mBot v1.1 ima: programiranje tijela robota, programiranje raznih senzora (zvučni, svjetlosni, za kretanje i izbjegavanje prepreka

49 Vidi više na mBot: one robot per child. [citirano:2018-05-24]. Dostupno na: http://store.makeblock.com/product/mbot-robot-kit.

50 Makeblock (www.makeblock.com) je otvorena open source robotska obrazovna platforma koja edukatorima i hobistima nudi razne mehaničke dijelove, elektroničke module, grafičke računalne programe i mrežno dostupne edukativne materijale (upute za korištenje, predavanja i sl.) za kreiranje ideja u STEM-području.

51 Arduino (www.arduino.cc) je otvorena open source računalna i softverska platforma koja dizajnerima i konstruktorima omogućava stvaranje uređaja i njihovo spajanje na računala. Kreirala ga je 2005. talijanska tvrtka SmartProjects da bi stvorila jednostavnu i jeftinu platformu s kojom bi se računala mogla lakše povezivati.

52 Za lakše učenje programa Scratch 2.0 za grafičko programiranje $m B l o c k$-opreme dostupni su digitalni priručnici na http://learn.makeblock.com/mbot-resource-download.

53 Bluetooth je bežična veza radiovalovima u frekvencijskom području od 2,4 do 2,48 $\mathrm{GHz} u$ promjeru od oko $10 \mathrm{~m}$ između dva ili više uređaja. Vidi više: Bluetooth. // Techopedia. [citirano: 2018-24-05]. Dostupno na: https://www.techopedia.com/definition/26198/bluetooth.

${ }^{54}$ Wireless je bežični prijenos informacija između dvije ili više točaka koje nisu spojene električnim vodičem. Vidi više: Wireless network. // Techopedia. [citirano: 2018-24-05]. Dostupno na: https:// www.techopedia.com/definition/26186/wireless-network.

55 Besplatno dostupan na mBlock. [citirano:2018-05-24]. Dostupno na: www.mblock.cc/. 
u prostoru, praćenje crne linije, bežični prijenos podataka). Osim za računala $P C$ i Apple, mBlock ima razvijene verzije aplikacija za tablet-računala i pametne telefone: Makeblock APP i mBlock APP..$^{56}$

Kod STEM-aktivnosti cilj je postizanje kompetencija i ključnih vještina kao što su vještine učenja, rješavanja problema, suradnje i komunikacije. Također, cilj je i poticanje znatiželje, inicijative, upornosti, prilagodljivosti, društvene i kulturne svjesnosti kod djece i mladih.

Nakon tri ciklusa programa GENERATOR Gradska knjižnica Zadar osnovala je tim iz robotike sastavljen od osam članova i prijavila se za sudjelovanje u posljednjem natjecateljskom kolu Croatian Makers lige u školskoj godini 2016./2017. Učenici osnovnoškolskog uzrasta koji su do tada sudjelovali u programu GENERATOR dodatno su se pripremali za natjecanje uz pomoć mentora, profesora informatike Željka Vidovića, u osnovnoj školi Šime Budinić u Zadru.

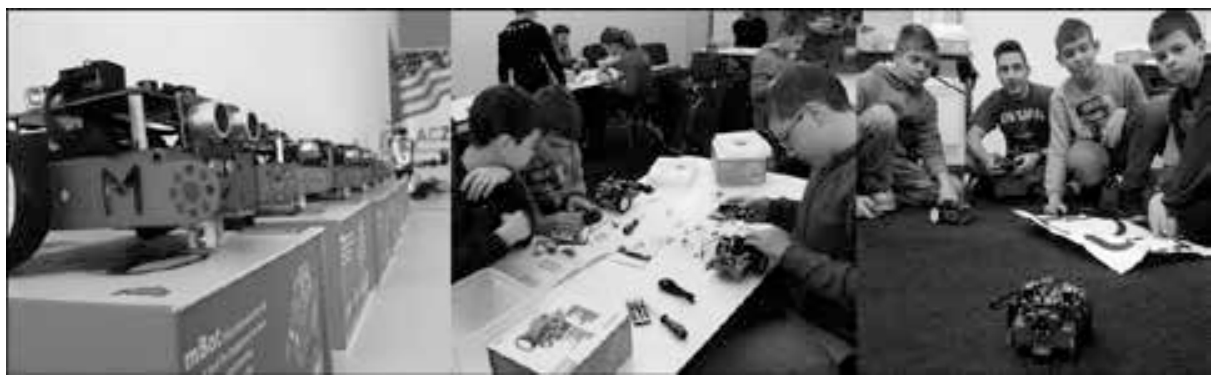

Slika 7. Radionica Robotika 1: mBot v1.1

\subsection{Radionica Robotika 2: LEGO Mindstorms EV3}

Posljednja, četvrta radionica u ciklusu GENERATOR jest upoznavanje s mogućnostima i programiranjem robota LEGO Mindstorms EV3 (slika 8). Taj robotski set polaznici ne sastavljaju zbog velike količine dijelova i vremenskog ograničenja radionice. Slaganje, funkcija i način korištenja čitavog niza dijelova (centralnog upravljačkog kontrolnog LEGO-bloka, senzora za boju, dodir i zvuk, infracrvenog senzora, motora za pokretanje, daljinskog upravljača i drugih) demonstrira se uz pomoć mrežno dostupnih uputa i primjera. ${ }^{57}$ Robot se pokreće i kontrolira pomoću aplikacija namijenjenih za tablet-računala i pametne telefone ${ }^{58}$ :

56 Besplatno dostupne na Makeblock. [citirano:2018-05-24]. Dostupno na: http://learn.makeblock.com/en/software/.

${ }_{57}$ Dostupni na www.lego.com/en-us/mindstorms/downloads/user-guide.

58 Besplatne verzije za Android i $i O S$ dostupne su na www.lego.com/en-us/mindstorms/apps. 
Robot Commander APP (kontroliranje kretanja), EV3 Programmer APP (grafičko programiranje, kontroliranje i upravljanje) i Fix The Factory Game (računalna igra kao logički alat za programiranje robotskog kretanja i svladavanje prostornih prepreka). Za računala $P C$ i Apple Macintosh razvijen je računalni program EV3 Programming Software ${ }^{59}$ koji na sličan način kao i računalni program $m B l o c k$ omogućuje brzo učenje osnova grafičkog programiranja.

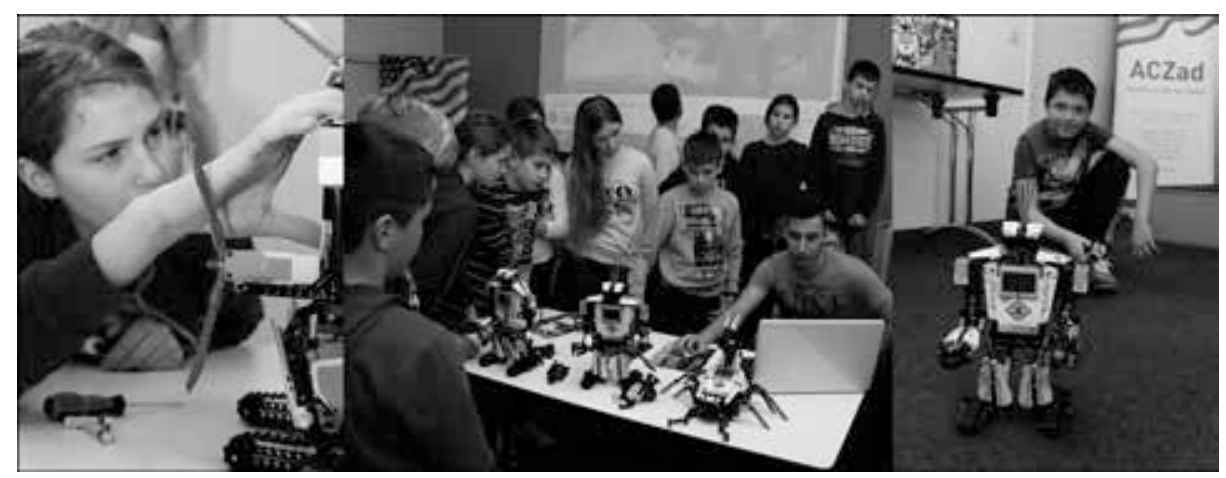

Slika 8. Radionica Robotika 2: LEGO Mindstorms EV3 1

\section{Anketa - program GENERATOR}

U razdoblju od prosinca 2016. do svibnja 2017. godine u Gradskoj knjižnici Zadar, uz usmeno odobrenje roditelja (vidi poglavlje 3.1.), provedena je interna anonimna anketa ${ }^{60}$ kvantitativnom metodom pismenog prikupljanja podataka za sudionike programa GENERATOR, vodeći računa o anonimnosti sudionika i zaštiti prava djeteta, odnosno uzimajući u obzir Etički kodeks istraživanja s djecom. ${ }^{61}$ Odabrana je zbog svoje pouzdanosti, jer je za očekivati da će ispitanici biti iskreni u davanju svojih odgovora. Anketirane su četiri grupe ispitanika tijekom četiri ciklusa programa, ukupno 46 djece i mladih. Anketa je sadržavala 6 kratkih jednostavnih pitanja zatvorenog tipa primjerenih djeci i mladima te prostor za komentare. S obzirom na dob ispitanika, karakter radionica i raznolikost interesa ispitanika, za svako postavljeno pitanje ponuđena je mogućnost davanja više od-

59 Dostupan na www.lego.com/en-us/mindstorms/downloads/download-software.

60 Više o evaluaciji, statistici i testiranju djece i mladih vidi u Braun, L.W. Teens.library: developing Internet servis for young adults. Chicago; London: American Library Association, 2002. Str. 60-63.

${ }^{61}$ Vidi više o istraživanju s djecom: Etički kodeks istraživanja s djecom / urednici Marina Ajduković i Vladimir Kolesarić. Zagreb : Državni zavod za zaštitu obitelji, materinstva i mladeži : Vijeće za djecu Vlade Republike Hrvatske, 2003. [citirano: 2018-10-03]. Dostupan na http:// www.ufzg.unizg.hr/wp-content/uploads/2013/12/Eticki-kodeks-istrazivanja-s-djecom.pdf. 
govora. Cilj ankete jest informiranje o interesima, potrebama i zadovoljstvu korisnika ponuđenim sadržajem prilikom sudjelovanja na edukativnim radionicama u području STEM-programa namijenjenih djeci i mladima.

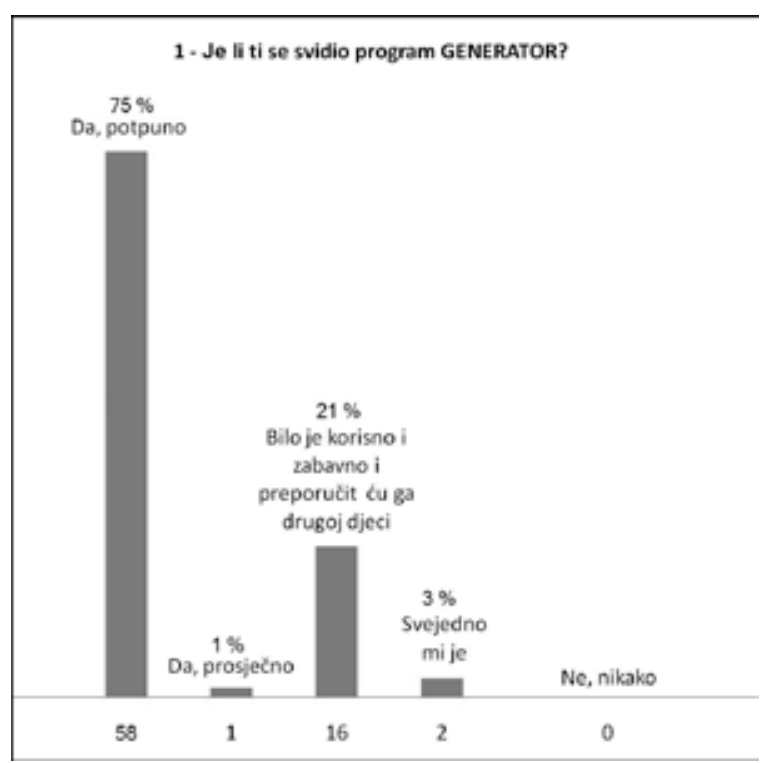

Slika 9. Percepcija zadovoljstva djece i mladih STEM-programom GENERATOR

Prema podacima dobivenim na temelju prvog anketnog pitanja (slika 9) i prema ukupnom broju odgovora o zadovoljstvu korisnika programom GENERATOR, vidljiv je izrazito visok stupanj zadovoljstva (97 \%).



Slika 10. Kanali informiranja djece i mladih o STEM-programu GENERATOR 
Na pitanje o načinu informiranja korisnika o programu GENERATOR (slika 10), $37 \%$ ispitanika odgovara da je za program saznalo od roditelja; $17 \%$ ispitanika informaciju o programu doznalo je putem plakata, a oko $17 \%$ saznalo ih je za program prilikom posjeta Knjižnici. U manjoj mjeri, između 7 \% i 10 \% slučajeva, kao oblik informiranja navodi se praćenje mrežnih stranica Knjižnice ili preporuka prijatelja i nastavnika.



Slika 11. Stupanj zadovoljstva djece i mladih STEM-radionicama u programu GENERATOR



Slika 12. Stupanj zadovoljstva djece i mladih ponuđenom STEM-opremom u programu GENERATOR 
S obzirom na ponuđeni program radionica i korištenje opreme, iz anketnih pitanja 3 i 4 (slika 11 i slika 12) vidljivo je da su se sudionicima programa GENERATOR u oko $85 \%$ slučajeva najviše i u podjednakoj mjeri svidjele radionice 3D-olovka i područje robotike. Smatramo da je uzrok većeg interesa za navedene radionice aktivno sudjelovanje $\mathrm{u}$ radionicama nakon prezentacije i demonstracije opreme: kreativan rad s 3D-olovkom, samostalno sastavljanje, programiranje i pokretanje robotskih setova. Također, $16 \%$ ispitanika navelo je radionicu 3D-printer i 3D-modeliranje kao interesantnu. Manja atraktivnost te radionice bila je očekivana. Takav tip radionice vremenski je ograničen i tehnološki zahtjevan. Osmišljen je kao demonstracija uređaja i računalnih programa u trajanju od 90 minuta. $S$ obzirom na to da je proces 3D-modeliranja i printanja vremenski zahtjevan, sudionici nisu u mogućnosti tijekom jedne radionice samostalno kreirati i isprintati vlastiti 3D-model. Cilj i plan organizatora programa GENERATOR jest omogućiti nastavak STEM-aktivnosti djeci i mladima uz odgovarajuće uvjete prema njihovim interesima i potrebama.

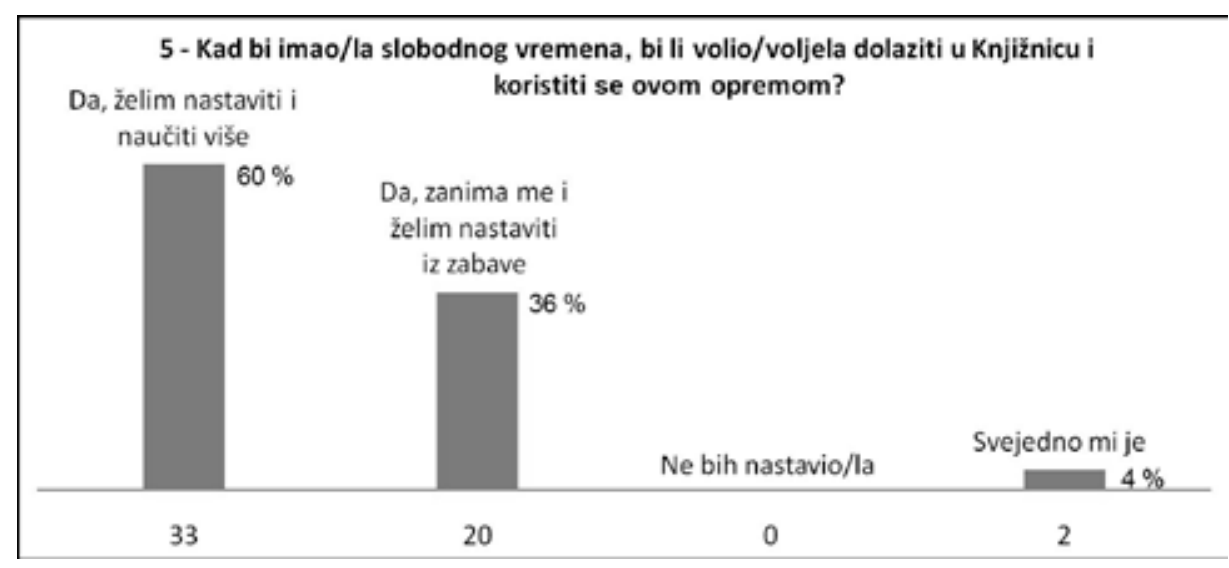

Slika 13. Interes djece i mladih za nastavak korištenja STEM-opreme u Gradskoj knjižnici Zadar

Ohrabrujuće je saznanje da više od $60 \%$ ispitanika (slika 13) želi nastaviti i naučiti više ako im se ponudi mogućnost daljnjeg sudjelovanja u STEM-programima u organizaciji Knjižnice, dok $36 \%$ ispitanika navodi da ih ti programi zanimaju samo radi zabave. 


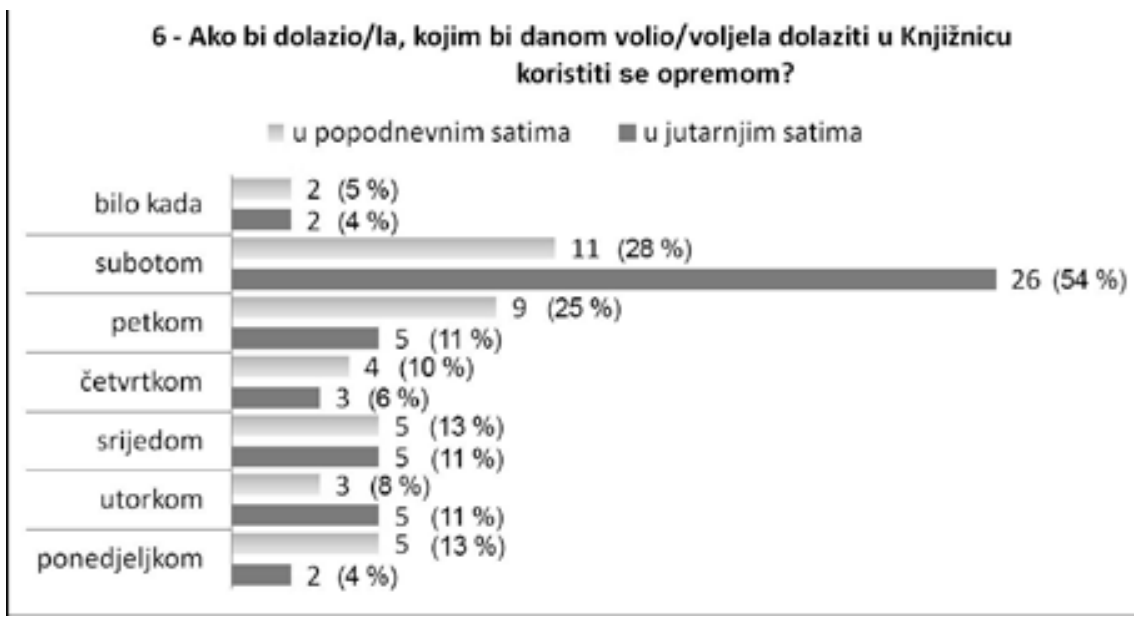

Slika 14. Pitanje o najpogodnijim danima u tjednu za korištenje STEM-opreme kod djece i mladih u Gradskoj knjižnici Zadar

Prema rezultatima iz anketnog pitanja 6 (slika 14) o korištenju slobodnog vremena djece i mladih, vidljiva je potvrda dosadašnje teze iz iskustva djelatnika Gradske knjižnice Zadar koja govori da djeca i mladi najviše slobodnog vremena za aktivnosti imaju subotom ujutro. Najveći broj ispitanika (54 \%) kao najpoželjniju mogućnost navodi taj termin.

Vidljiv je i potencijal kod oko $25 \%$ ispitanika koji bi željeli svoje slobodno vrijeme koristiti za STEM-programe petkom ili subotom popodne.

Napomenimo, oko $10 \%$ ispitanika bilo bi spremno izdvojiti svoje slobodno vrijeme bilo kojim danom ujutro ili popodne tijekom nastavnog tjedna za rad $\mathrm{s}$ ponuđenom STEM-opremom ili sudjelovanje u eventualnoj daljnjoj edukaciji.

\section{Daljnji razvoj STEM-programa u Gradskoj knjižnici Zadar}

Darovita i napredna djeca željna su znanja i novih izazova. U suorganizaciji zadarskog Centra izvrsnosti ${ }^{62}$ za fiziku i Gradske knjižnice Zadar provodi se i projekt Mali znanstvenici ${ }^{63}$ u kojem djeca i mladi kroz niz edukativnih radionica imaju priliku na kreativan i zabavan način eksperimentirati i stjecati nova znanja. Mentorice su profesorice fizike Ana Lipošćak iz osnovne škole Šime Budinić i Vedrana Kasalo iz osnovne škole Bartol Kašić u Zadru. Američki kutak Gradske knjižnice

62 Vidi više na Grad Zadar. [citirano:2018-05-24]. Dostupno na: www.grad-zadar.hr/centri-izvrsnosti-za-matematiku-fiziku-i-informatiku-952/.

63 Vidi više: Bakmaz, M. Projekt Mali znanstvenici 2016. u Gradskoj knjižnici Zadar. // HKD Novosti 73(2017). [citirano: 2017-2-12]. Dostupno na: http://hkdrustvo.hr/hkdnovosti/clanak/1352. 
Zadar pored STEM-programa GENERATOR od 2017. godine podupire i program Mali znanstvenici kako bi se i nadalje osiguralo poticajno okruženje u kojem djeca i mladi mogu ostvariti svoju znatiželju i razne potencijale. Cilj je suradnje jačanje i širenje međuinstitucionalne suradnje, razmjena iskustava i resursa te zajednička promocija edukativnih STEM-programa. Za tu je svrhu, pored postojećih, nabavljen i niz dodatnih edukativnih setova i opreme (slika 15) za proučavanje raznih STEM-područja: robotika, jednostavni strojevi, mehanički sistemi, pneumatika, potencijalna i kinetička energija, proizvodnja električne energije, održivi izvori energije, elektricitet, elektronika, optika, digitalne komunikacije, programski kontrolirani sistemi itd.

\begin{tabular}{|c|c|c|c|}
\hline \multicolumn{4}{|l|}{ „Mali znanstvenici” oprema } \\
\hline \begin{tabular}{|l|} 
LEGO Education We Do Construction Set \\
edukocijski set, groficko progromironje modelo
\end{tabular} & 4 & www.education.lego.com & Www.idadidacta.hr \\
\hline $\begin{array}{l}\text { LEGO Education WeDo Construction Extra Set } \\
\text { dodatok zo LEGO Edu. We Do Construction Set }\end{array}$ & 4 & www.education.lego,com & www.idadidacta.hr \\
\hline $\begin{array}{l}\text { LEGO Pneumatics Add-on Set } \\
\text { pneumatiko, edukacijski konstrukcijski set: } \\
\text { pumpe, cijewi, ventili, manometor... }\end{array}$ & 2 & www.education.lego.com & www.idadidacta.hr \\
\hline $\begin{array}{l}\text { LEGO Renewable Energy Add-on Set } \\
\text { odrilwi irvori energije, edukocijski solomi set: } \\
\text { vietrenjakto, ventilatori... }\end{array}$ & 2 & www.education.lego.com & www.idadidacta.hr \\
\hline $\begin{array}{l}\text { Fischer Technik Edu (STEM PREP Physics, } \\
\text { Robotics, Energy \& Power Set) } \\
\text { edukocijski konstrukcijski set: mehaniko, } \\
\text { pneumotika, elektriǐna energija, } \\
\text { optika, digitalne komunilkacije }\end{array}$ & 1 & www.fischertechnik.de & www.didacta.hr \\
\hline $\begin{array}{l}\text { Fischer Technik Edu } \\
\text { (Robotics Competition Set) } \\
\text { groficko programironje: kamera, motori, } \\
\text { senzori za ultrazvuk, boju, toplinu, } \\
\text { Eiro senzor, akcelerometar, kompos...) }\end{array}$ & 1 & www.fischertechnik.de & www.didacta.hr \\
\hline
\end{tabular}

Slika 15. Popis opreme namijenjene programu Mali znanstvenici

Izbor raznovrsnih STEM-radionica kroz edukaciju i igru potiče rješavanje najrazličitijih logičkih zadataka i problema, apstraktno razmišljanje, planiranje i pregovaranje. Tim programima potiče se suradnja, analiziranje, sintetiziranje i tumačenje raznih logičkih rješenja, a neki od njih potiču razumijevanje prostora i prostornih odnosa, razvojno su izazovni i uspješno spajaju kreativnost, analitički um i vedro raspoloženje kod djece i mladih.

Razvijaju se logičko-matematičke vještine (razmišljanje i shvaćanje matematičkih pojmova kao što su veličina, oblik, količina, brojevi, aritmetički znakovi, razvrstavanje, simetrija, mjerenje i sl.), mašta (mašta kao stvaralačko mišljenje predstavlja osnovu umjetničke, znanstvene i tehničke kreativnosti) i kreativnost. 
Igra kod djece razvija kreativnost i maštu, učvršćuje mentalne vještine (osigurava mogućnost za isprobavanje novih ideja i razmišljanja na nov način) i spoznajni razvoj (istraživanje novoga, stjecanje iskustava i bogaćenje znanja).

\section{Zaključak}

Narodne knjižnice su ustanove koje mogu i trebaju, prema svojim mogućnostima, omogućiti djeci i mladima privlačno okruženje za kreativan rad, edukaciju, upoznavanje, usmjeravanje, osvještavanje i primjenu novih tehnologija. Gradska knjižnica Zadar, pod utjecajem novih tehnologija i novih medija, uvodi nove knjižnične usluge i zbirke te organizira razne aktivnosti za edukaciju korisnika o korištenju tehnologije. Posebna briga posvećena je radu s djecom i mladima, kojima su osobito zanimljivi edukativni STEM-programi.

Američki kutak Gradske knjižnice Zadar inicijator je i organizator edukativnog STEM-programa GENERATOR: radionice na struju koji se realizira u suradnji s učenicima i profesorima Strukovne škole Vice Vlatković u Zadru. Program GENERATOR, kao i ostali STEM-programi ponuđeni djeci i mladima u Gradskoj knjižnici Zadar, inovativan je te po uzoru na druge inicijative u Hrvatskoj prati globalne i lokalne trendove na području STEM-edukacije. Knjižničari i učenici osnovnih i srednjih škola aktivni su sudionici tih programa. Pripremom programa, razmjenom iskustava i edukacijom djece i mladih razvijaju se vještine i stječu nova znanja. Opisani primjeri STEM-radionica (3D-printer, 3D-olovka, robotika i drugi) donose niz tehničkih podataka i popisa opreme koji su korisni knjižničarima koji bi željeli organizirati takve programe u svojim sredinama. Napomenimo, upravo organizacija i kontinuirano provođenje edukativnih STEM-programa, poticanje na inovativan i kreativan rad te usmjeravanje i osvještavanje primjene novih tehnologija kod djece i mladih značajni su za njihovo snalaženje, odabir, odnosno ulazak u svijet budućih potencijalnih STEM-zanimanja.

Provedena anketa o zadovoljstvu polaznika ponuđenim edukativnim STEM-programom GERNERATOR u Gradskoj knjižnici Zadar ukazuje na izrazito visok stupanj zadovoljstva (97\%). STEM-programi privlače djecu i mlade zanimljivim sadržajima. Više od 60 \% ispitanika želi nastaviti i naučiti više ako im se omogući daljnje sudjelovanje u STEM-programima u organizaciji Knjižnice, a $36 \%$ ispitanika STEM-programi interesiraju samo radi zabave. Rezultati istraživanja, kao i interes djece i mladih za STEM-programe, poticaj su i potvrda Gradskoj knjižnici Zadar u nastojanjima da osigura uvjete za razvoj STEM-programa. Jačanjem međuinstitucionalne suradnje, nabavom nove opreme i uvođenjem novih sadržaja, uz potporu Američkog kutka Gradske knjižnice Zadar postojećim STEM-programima (GENERATOR, Mali znanstvenici), djeca i mladi imaju priliku nastaviti na kreativan i zabavan način eksperimentirati, stjecati nova znanja te razvijati svoje potencijale na raznim STEM-područjima. U skoroj budućnosti, 
proširenjem Knjižnice, odnosno planiranjem, osmišljavanjem i opremanjem primjerenog prostora namijenjenog STEM-programima, kvaliteta usluge edukativnih STEM-programa podići će se na višu razinu.

\section{LITERATURA}

Acrylonitrile Butadiene Styrene (ABS). // Techopedia. [citirano: 2017-14-11]. Dostupno na: https://www.techopedia.com/definition/29375/acrylonitrile-butadiene-styrene-abs.

Baek, J. Y. Public libraries as places for STEM Learning: an exploratory interview study with eight librarians: education/research report. Boulder, Co.: National Center for Interactive Learning, 2013. Str. 4-11. [citirano: 2018-22-03]. Dostupno na: http:// www.nc4il.org/images/papers/Baek_Public\%20Libraries\%20as\%20Places\%20 for\%20STEM\%20Learning.pdf.

Bakmaz, M. Projekt Mali znanstvenici 2016. u Gradskoj knjižnici Zadar. // HKD Novosti 73(2017). [citirano: 2017-2-12]. Dostupno na: http://hkdrustvo.hr/hkdnovosti/ clanak/1352.

Belevski, M. Američki kutak Zadar. // Knjižnica komunikacijsko i multikulturalno središte lokalne zajednice : zbornik radova / priredila za tisak Jelica Leščić. Zagreb: Nacionalna i sveučilišna knjižnica, 2012. Str. 331-336.

Belevski, M.; S. Segarić. iPad i u našoj školi - iPad in Our School. // Stručni skup Dječja knjižnica, danas i njezina odgojno obrazovna dimenzija: zbornik radova / uredili Marina Šimić i Vilijam Lakić. Šibenik: Gradska Knjižnica Juraj Šižgorić, 2017. Str. 61-76.

Božić, I. Evo što znači i koja područja obuhvaća STEM. [citirano: 2017-20-11]. Dostupno na: www.srednja.hr/zbornica/nastava/evo-sto-znaci-i-koja-podrucja-obuhvacastem/.

Braun, L.W. Teens.library: developing Internet servis for young adults. Chicago; London: American Library Association, 2002.

Brunac, D. Recenzija Smjernica za knjižnične usluge za mladež. // Vjesnik bibliotekara Hrvatske 53, 1 (2010), 135-142. Dostupno i na: https://www.Hrvatsko knjižničarsko društvorustvo.hr/vjesnik-bibliotekara-hrvatske/index.php/vbh/article/view/450/445 [citirano: 2017-15-11].

Bluetooth. // Techopedia. [citirano: 2018-24-05]. Dostupno na: https://www.techopedia. com/definition/26198/bluetooth.

Da Vinci 1.1 Plus. [citirano: 2017-14-11]. Dostupno na: www.xyzprinting.com/en-GB/ product/da-vinci-1-1plus. 
Dusenbery, P. B. The STEM education movement in public libraries. // Informal Learning Review 124(2014), 14-19. [citirano: 2018-22-03]. Dostupno na: https://www. lpi.usra.edu/education/stemlibraryconference/events/ILR_STEM_Library_Paper. pdf.

Etički kodeks istraživanja s djecom / urednici Marina Ajduković i Vladimir Kolesarić. Zagreb : Državni zavod za zaštitu obitelji, materinstva i mladeži : Vijeće za djecu Vlade Republike Hrvatske, 2003. [citirano: 2018-10-03]. Dostupno na: http://www. ufzg.unizg.hr/wp-content/uploads/2013/12/Eticki-kodeks-istrazivanja-s-djecom. pdf.

Fused Filament Fabrication (FFF). // Techopedia. [citirano: 2017-14-11]. Dostupno na: https://www.techopedia.com/definition/29377/fused-filament-fabrication-fff.

Flowers, S. Young adults deserve the best YALSA's competencies in action. Chicago: American Library Association, 2011.

Grad Zadar. [citirano:2018-05-24]. Dostupno na: www.grad-zadar.hr/centri-izvrsnosti-za-matematiku-fiziku-i-informatiku-952/.

Gradska knjižnica Zadar. Generator. [citirano: 2017-25-11]. Dostupno na: www.gkzd. $\mathrm{hr} /$ content/generator-1.

Gradska knjižnica Zadar 2012.: godišnje izvješće / urednik Mladen Masar. Zadar: Gradska knjižnica, 2012. [citirano: 2017-25-11]. Dostupno i na: www.gkzd.hr/sites/ default/files/gi_2012_w.pdf.

Gradska knjižnica Zadar. Poslanje. [citirano: 2017-25-11]. Dostupno na: http://www. gkzd.hr/content/poslanje-gradske-knji\%C5\%BEnice-zadar.

Gradska knjižnica Zadar. Strategija razvoja od 2017. do 2020. godine. [citirano: 201725-11]. Dostupno na: http://www.gkzd.hr/sites/default/files/sluzbene_informacije/ Strategija_Gradske_knjiznice_Zadar_od_2017_do_2020.pdf.

Hakala, J.S.; K. MacCarthy; C. Dewaele; M. Wells; P. B. Dusenbery; K. LaConte. STEM in public libraries : national survey results. 2016. [citirano: 2018-22-03]. Dostupno na: http://www.nc4il.org/images/papers/FINAL_STEM_LibrarySurveyReport.pdf.

IFLA-ine i UNESCO-ove smjernice za školske knjižnice. Zagreb : Hrvatsko knjižničarsko društvo, 2004.

IFLA-ine smjernice za knjižnične usluge za djecu. Zagreb : Hrvatsko knjižničarsko društvo, 2004.

IFLA-ine smjernice za knjižnične usluge i mladež. Zagreb : Hrvatsko knjižničarsko društvo, 2009.

Intel RealSense Technology : Observe the World in 3D. [citirano: 2017-10-11]. Dostupno na: www.intel.com/content/www/us/en/architecture-and-technology/realsense-overview.html.

iPad radionica. // Gradska knjižnica Zadar. [citirano: 2018-05-24]. Dostupno na: www. gkzd.hr/tagovi/ipad-radionica. 
Jelušić, S.; I. Stričević. Knjižnične usluge za mlade : modeli i koncepti // Vjesnik bibliotekara Hrvatske 53, 1 (2010), 1-34. Dostupno i na: https://www.Hrvatsko knjižničarsko društvorustvo.hr/vjesnik-bibliotekara-hrvatske/index.php/vbh/article/view/443 [citirano: 2017-9-11].

Kiš, M. Englesko-hrvatski informatički rječnik. Zagreb: Naklada Ljevak, 2000.

Lončar, M.; I. Klak Mršić. Američki kutak Zagreb: pogled unatrag, pogled unaprijed. // HKD Novosti 73(2017). [citirano: 2017-9-11]. Dostupno na: https://www.hkdrustvo.hr/hkdnovosti/clanak/1350.

Makeblock. [citirano:2018-05-24]. Dostupno na: http://learn.makeblock.com/en/software/.

mBlock. [citirano:2018-05-24]. Dostupno na: www.mblock.cc/.

mBot: one robot per child. [citirano:2018-05-24]. Dostupno na: http://store.makeblock. com/product/mbot-robot-kit.

Pandžić, I.S. Virtualna okruženja: računalna grafika u stvarnom vremenu i njene primjene. Zagreb: Element, 2004.

Polylactic Acid (PLA). // Techopedia. [citirano: 2017-14-11]. Dostupno na: https:// www.techopedia.com/definition/29379/polylactic-acid-pla.

ScratchJr: coding for young children.[citirano:2018-05-24]. Dostupno na: http://www. scratchjr.org/.

Sense: 3D scanner. [citirano:2018-05-24]. Dostupno na: www.3dsystems.com/shop/ sense.

Shtivelband, A; L. Riendeau; A. Wallander-Roberts; R. Jakubowski. Implementing effective STEM programming in public libraries : eight recommendations : report to Space Science Institute's National Center for Interactive Learning. 2016. [citirano: 2018-22-03]. Dostupno na: http://www.nc4il.org/images/papers/Research-White-Paper-121216.pdf.

STEAM programming toolkit : science, technology, engineering, arts \& math. YALSA, 2016. [citirano: 2018-22-03]. Dostupno na: http://www.ala.org/yalsa/sites/ala.org. yalsa/files/content/2016STEAM\%20TOOLKIT.pdf.

STEM obrazovanje - od predškolarca do studenta. [citirano: 2017-20-11]. Dostupno na: www.maligenijalci.com/stem-obrazovanje-od-predskolarca-studenta.

STEM (science, technology, engineering, mathematics) programming. [citirano: 2018-22-03]. Dostupno na: https://youthserviceslibrarianship.wikispaces.com/ STEM+\%28Science $\% 2 \mathrm{C}+$ Technology $\% 2 \mathrm{C}+$ Engineering $\% 2 \mathrm{C}+$ Mathematics\%29+Programming.

STL (Standard Triangle/Tessellation Language) reader/writer. [citirano: 2017-7-11]. Dostupno na: https://docs.safe.com/fme/html/FME_Desktop_Documentation/ FME_ReadersWriters/stl/stl.htm. 
Stričević, I. Dječja knjižnica ukorak s vremenom. // Dječja knjižnica za novo tisućljeće : zbornik radova / priredila Ranka Javor. Zagreb : Knjižnice grada Zagreba, 2001. Str. 6-11.

Štefančić, S. Uvodna riječ. // Knjižnica i mediji : zbornik radova / priredili Ranka Javor i Silko Štefančić. Zagreb : Knjižnice grada Zagreba, 2006. Str. 5-6.

Učenici Strukovne škole Vice Vlatković pobjedom u Zagrebu osigurali nastup u Šangaju. [citirano: 2017-12-11]. Dostupno na: https://ezadar.rtl.hr/dogadaji/2726181/ ucenici-strukove-skole-vice-vlatkovic-pobjedom-u-zagrebu-osigurali-nastup-u-sangaju/.

What is a makerspace? [citirano:2018-05-24]. Dostupno na: www.makerspaces.com/ what-is-a-makerspace.

Wireless network. // Techopedia. [citirano: 2018-24-05]. Dostupno na: https://www.techopedia.com/definition/26186/wireless-network.

XYZscan handy. [citirano:2018-05-24]. Dostupno na: https://www2.xyzprinting.com/ en-GB/software/xyzscan-handy.

XYZmaker 1.0. [citirano:2018-05-24]. Dostupno na: www.xyzprinting.com/en-GB/software/xyzmaker.

XYZprinting 3D: scanner 1.0A. [citirano:2018-05-24]. Dostupno na: www.xyzprinting. com/en-GB/product/3d-scanner-pro.

XYZprinting da Vinci 1.1 Plus User Manual. [citirano: 2018-15-04]. Dostupno na: https:/www.manualslib.com/manual/1034975/Xyz-Printing-Da-Vinci-1-1-Plus. html.

XYZware: [citirano:2018-05-24]. Dostupno na: www.xyzprinting.com/en-GB/software/xyzware. 


\section{Prilog:}

\section{ANKETA „GENERATOR: radionice na struju“ (Gradska knjižnica Zadar)}

1) Je li ti se svidio program GENERATOR?

$\square \mathrm{Da}$, potpuno. $\square$ Svejedno mi je.

$\square \mathrm{Da}$, prosječno. $\square \mathrm{Ne}$, nikako.

$\square$ Da, bilo je korisno i zabavno i preporučit ću ga drugoj djeci.

2) Kako si saznao/la za program GENERATOR?

$\square$ Vidio/la sam plakat. $\square$ Vidio/la sam na webu.

$\square$ Rekli su mi roditelji. $\square$ Čuo/la sam od prijatelja.

$\square$ Bio/la sam u knjižnici. $\square$ Rekli su mi u školi.

$\square$ Nešto drugo (navedi):

3) Koje su ti se radionice svidjele?

$\square$ 3D-printer i modeliranje. $\square$ 3D-olovka, 3D-skener i iPad.

$\square$ Robotika mBot v1.1 i programiranje robota.

$\square$ Robotika LEGO Mindstorm EV3.

4) Što ti se sve od opreme svidjelo?

$\square$ 3D-printer. $\square$ 3D-olovka.

$\square$ 3D-skener. $\square$ iPad.

$\square$ Robot mBot v1.1. $\square$ Robot LEGO Mindstorm EV3. 
5) Kad bi imao/la slobodnog vremena, bi li volio/voljela nastaviti dolaziti u Knjižnicu i koristiti se ovom opremom?

$\square \mathrm{Da}$, želim nastaviti i naučiti više. $\square$ Ne bih nastavio/la.

$\square$ Da, zanima me i želim nastaviti iz zabave. $\square$ Svejedno mi je.

6) Ako bi dolazio/la, kojim bi danom volio/voljela dolaziti u Knjižnicu i koristiti se opremom?

$\square$ ponedjeljak $\square$ ujutro $\square$ popodne

$\square$ utorak $\square$ ujutro $\square$ popodne

$\square$ srijeda $\square$ ujutro $\square$ popodne

$\square$ četvrtak $\square$ ujutro $\square$ popodne

$\square$ petak $\square$ ujutro $\square$ popodne

$\square$ subota $\square$ ujutro $\square$ popodne

$\square$ bilo kada

Tvoj kratki komentar i preporuka za program GENERATOR (napiši ako želiš): 